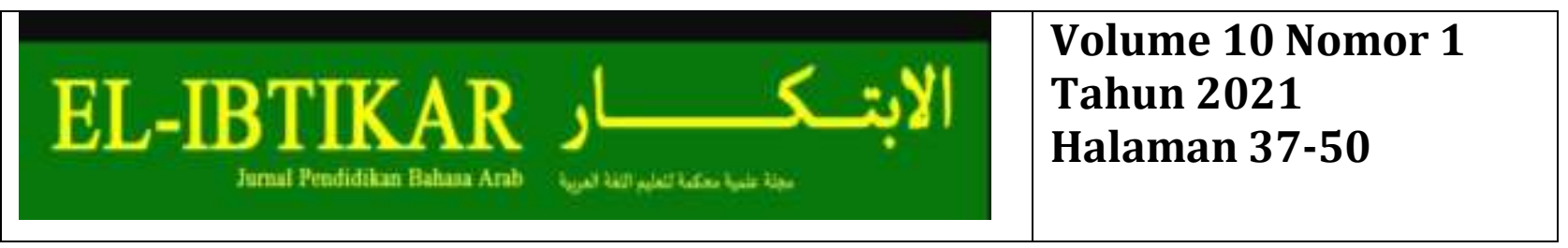

\title{
Faktor-faktor Penghambat dalam Memahami Bahasa Arab
}

\author{
Yaris Eka Rachman Tatang \\ Email: yarisstrashshaff@gmail.com \\ Shofa Musthofa Khalid \\ Program Studi Pendidikan Bahasa ArabFakultas Pendidikan Bahasa Dan Sastra \\ Universitas Pendidikan Indonesia
}

Diterima artikel: 07 Januari 2021

Diterbitkan artikel: 16 Juni 2021

\begin{abstract}
Abstarct
Language is a system of sound symbols that humans use to communicate to express their thoughts and feelings. One of the languages used by humans is Arabic. Arabic has an important importance in the daily life of a Muslim. Therefore a Muslim is required to learn and understand Arabic. However, in the learning process, several inhibiting factors emerged that were felt by Arabic learners in understanding Arabic. Among the inhibiting factors are the lack of motivation to learn, lack of training in their skills, low interest in memorizing new vocabulary, and not learning materials, lack of learning facilities, unstructured material, and lack of Arabic reading books. In dealing with these inhibiting factors for learning Arabic, there are several solutions that can be done, such as praying to Allah, creating a good environment, and managing time well.
\end{abstract}

Keywords: Learning Arabic, Urgency, Inhibiting factors, and solutions

\begin{abstract}
Abstrak
Bahasa adalah sistem lambang bunyi yang digunakan manusia untuk berkomunikasi mengungkapkan pikiran dan perasaannya. Salah satu bahasa yang digunakan manusia adalah bahasa Arab. Bahasa Arab memiliki urgensi penting dalam kehidupan seharihari seorang muslim. Karenanya seorang muslim dituntut untuk memelajari dan memahami Bahasa Arab. Namun dalam proses pembelajrannya muncul beberapa faktor penghambat yang dirasakan pelajar bahasa Arab dalam memahami Bahasa Arab. Diantara faktor pemnghambat tersebut adalah adalah kurangnya motivasi belajar, kurang melatih kemampuan yang dimiliki, rendahnya minat untuk menghafal kosa kata baru, dan tidak memurajaah materi, minimnya fasilitas belajar, materi yang tidak
\end{abstract}


terstruktur, dan kuragnya buku bacaan Bahasa Arab,. Dalam menghadapi faktor-faktor penghambat pembelajaran Bahasa Arab tersebut ada beberapa solusi yang bisa dilakukan seperti berdo'a kepada Allah, menciptakan lingkungan yang baik, serta mengatur

waktu dengan baik.

Kata Kunci: Pembelajaran bahasa Arab, Urgensi, Faktor penghambat, dan solusi

\section{Pendahuluan}

Pendidikan adalah kebutuhan setiap manusia, kerena dengannya, manusia dapat saling mewariskan pengalaman hidupnya kepada orang lain. Terlebih pendidikan yang berkenaan dengan bahasa Arab yang merupakan bahasa yang tidak asing bagi umat islam, karena Al-Qur'an, hadits, dan kitab para ulama, termaktub dengan bahasa Arab. Maka tidak akan mungkin dipahami, kecuali dengan memperlajari bahasa itu sendiri.

Bahasa Arab memiliki peranan penting dalam kehidupan sehari-hari, karena jikalau diperhatikan hari-hari seorang muslim dimulai dengan bahasa Arab, dan ditutup dengan bahasa Arab pula. Sebagai contoh nyatanya, ketika bangun tidur, seorang muslim membaca doa dengan bahasa Arab, kemudian beranjak ke kamar mandi, dan keluar, menggunakan bahasa Arab pula. Berakhir dengan dzikir sebelum tidur dengan menggunakan bahasa Arab. Ini menujukkan bahwa hubungan seorang muslim dengan bahasa Arab sangatlah erat, tidak dapat dipisahkan.

Tentunya dalam memperlajari bahasa Arab, di dalamnya terdapat cabang-cabang pelajaran tersendiri, mulai dai nahwu, sharaf, balaghah, i'rab, dan yang lainnya. Seorang pelajar dituntut untuk menguasai cabang-cabang tersebut guna mencapai tujuan untuk menguasai bahasa Arab ini, dan telah diketahui bersama, bahwasanya bahasa Arab ini perlu mengandalkan kecerdasan, dan juga kejelian dalam mempelajarinya. Semoga Allah mudahkan urusan kita semua. Aamiin.

Di dalam pelaksanaan pembelajaran bahasa Arab, terkadang dijumpai beberapa pelajar yang merasa kesulitan, dan juga menyerah untuk mempelajari bahasa Arab ini, karena didalamnya mereka dibebani untuk penerapan materi, menghafal kosakata, atau pesan-pesan yang diberikan oleh gurunya. Banyak didapati mereka mengeluh dengan rasa tidak suka terhadap bahasa Arab, sehingga bahasa ini menjadi beban baginya, dan tidak 
memberikan manfaat. Ini sangat disayangkan, apalagi bahasa Arab akan banyak terpakai dalam kehidupan sehari-hari, sebagaimana telah disebukan di awal-awal.

Oleh sebab itu, kami tertarik untuk mengupas lebih dalam mengenai faktor-faktor penghambat yang ada pada diri pelajar sehingga mereka merasa kesusahan untuk memahami bahasa Arab ini, dan dengan dasar itu, kami mencoba untuk memberikan solusi bagi mereka yang hendak mendalami bahasa yang mulia ini.

\section{Pembahasan}

\section{Pengertian Pembelajaran Bahasa Arab}

Bahasa tidak dapat dilepaskan dari kehidupan manusia. Dengan bahasa setiap manusia saling berkumikasi dan menyampaikan pikirannya.

Menurut kamus besar bahasa Indonesia, bahasa adalah sistem lambang bunyi yang berartikulasi (yang dihasilkan alat-alat ucap) yang bersifat sewenang-wenang dan konversional yang dipakai sebagai alat komunikasi untuk melahirkan perasaan dan pikiran, perkataan-perkataan yang dipakai oleh suatu bangsa (suku bangsa, Negara, daerah), dan perkataan yang baik, sopan-santun, tingkah laku yang baik.

Dari pengertian tersebut dapat diuraikan menjadi :

1. Bahasa sebagai sebuah sistem

Maksudnya dalam kegiatan berbahasa tidaklah bebas begitu saja tetapi terikat dengan kaidah-kaidah tertentu seperti gramatikal.

2. Bahasa pada dasarnya adalah bunyi

Ada 4 kemampuan berbahasa yang harus dikuasai oleh seseorang yaitu mendengar, berbicara, membaca, dan menulis. 2 kemampuan berbahasa yang paling awal yaitu mendengar dan berbicara berhubungan dengan bahasa lisan (bunyi) sedangkan membaca dan menulis berhubungan dengan tulisan yang merupakan proses berbahasa kedua.

3. Bahasa adalah lambang/simbol

Bahasa adalah simbol-simbol tertentu, ketika pebicara mengatakan "kursi" maka ia menggambarkan kursi pada hakikatnya. 
4. Bahasa untuk melahirkan perasaan dan pikiran.

Bahasa adalah alat yang digunakan untuk mengungkapkan apa yang dipikirkan oleh seseorang. Selain itu bahasa juga digunakan untuk mengungkapkan perasaan seseorang, ha ini dapat kita lihat ketika seseorang memperlihatkan perasaan senang,sedih, cemas, dan sebagainya dalam sebuah interaksi.

Salah satu bahasa yang digunakan manusia adalah bahasa Arab. Bahasa Arab digunakan oleh masyarakat luas di daerah jazirah Arab. Menurut Al-Ghalayin, bahasa arab adalah kalimat-kalimat yang dipergunakan oleh orang arab untuk mengungkapka tujuantujuan (pikiran dan perasaan) mereka.

Bahkan bahasa Arab digunakan oleh penduduk non-Arab terutama mereka yang beragama Islam karena bahasa ini digunakan dalam Al-Qur'an dan Hadits yang merupakan pedoman hidup seorang muslim. Selain itu bahasa Arab tidak terlepas dari kehidupan seorang muslim di manapun mereka berada, karena bahasa ini digunakan dalam setiap peribadatannya seperti shalat, berdoa, dan sebagainya.

Sedangkan pembelajaran adalah proses interaksi peserta didik dengan pendidik dan sumber belajar pada suatu lingkungan belajar baik lingkungan pendidikan formal maupun nonformal (Depdiknas. 2002).

Dalam keputusan menteri agama nomor 183 tahun 2019 disebutkan bahwa pembelajaran bahasa Arab di madrasah secara bertahap dan holistik diarahkan untuk menyiapkan peserta didik memiliki kecakapan berbahasa, yaitu:

1. Mampu mengapresiasikan perasaan, pikiran, dan gagasan secara verbalkomunikatif.

2. Mampu menginternalisasi keterampilan berbahasa Arab dengan baik sehingga peserta didik menjadi terampil menggunakan bahasa Arab dalam berbagai situasi.

3. Mampu menggunakan bahasa Arab untuk mempelajari ilmu-ilmu agama, pengetahuan umum dan kebudayaan.

4. Mampu mengintegrasikan kemampuan berbahasa Arab dengan perilaku yang tercermin dalam sikap toleran, berfikir kritis dan sistematis.

\section{Urgensi Pembelajaran Bahasa Arab}


Pentingnya pembelajaran bahasa Arab bagi manusia terutama seorang muslim sangatlah jelas. Bahasa Arab tidak terlepas dari kehidupan sehari-hari seorang muslim. Terutama dalam beribadah seperti shalat, berdo'a, berdzikir, naik haji, dan sebagainya.

Al-Qur'an dan Hadits yang merupakan pegangan bagi seorang muslim sebagaimana disebutkan dalam sebuah hadits yang dinilai hasan oleh Syaikh Al-Albani dalam Misykaatul Mashaabih, hadits no. 186, Rasulullah bersabda:

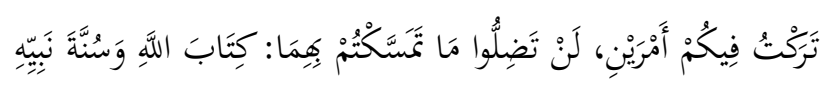

"Aku tinggalkan sesuatu bersama kalian, jika kamu berpegang teguh padanya, kalian tidak akan tersesat selama-lamanya yaitu Kitabullah dan Sunnahku." (HR. Imam Malik dalam AlMuwaththa' 2/899)

Sudah kita ketahui bersama bahwasannya Al-Qur'an diturunkan dalam bahasa Arab sebagaimana firman Allah Ta'ala:

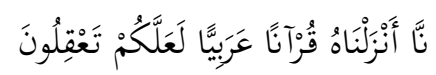

"Sesungguhnya Kami telah jadikan Al-Quran dalam bahasa Arab supaya kalian memikirkannya." (QS. Yusuf [12]: 2)

Disamping itu bahasa Arab merupakan bahasa yang digunakan pada zaman Rasulullah dimana hadits, dan ilmu-ilmu Islam disampaikan dengan bahasa Arab. Haditshadits dan ilmu-ilmu yang telah disampaikan tidak bisa dimengerti oleh seorang muslim kecuali mereka memahami bahasa Arab itu sendiri.

Karena mempelajari bahasa Arab sangat penting bagi seorang muslim, sebagian ulama mewajibkan mempelajarinya. Dalam kitab Iqtidho' Shirotil Mustaqim, hal. 207 Syaikhul Islam Ibnu Taimiyah rahimahullah berkata: "Dan sesungguhnya bahasa Arab itu sendiri bagian dari agama. Hukum mempelajarinya adalah wajib, karena memahami AlQur'an dan As-Sunnah itu wajib, dan keduanya tidaklah bisa dipahami kecuali dengan memahami bahasa Arab. Hal ini sesuai dengan kaidah di dalam ilmu ushul fiqh: sebuah kewajiban yang tidak akan sempurna (pelaksanaannya) kecuali dengan melakukan sesuatu (yang lain), maka sesuatu yang lain tersebut hukumnya juga menjadi wajib." 
Imam Adz-Dzahabi rahimahulah pernah menuliskan dalam kitabnya "Siyar A'lamin Nubala" bahwa Imam Syafi'i mengatakan: "tidaklah orang-orang itu menjadi bodoh dan banyak berselisih kecuali disebabkan mereka meninggalkan bahasa Arab dan lebih condong kepada perkataan Aristoteles."

Maksudnya bahwa kaum muslimin tidak akan bodoh dan berselisih dalam urusan agama kecuali jika mereka meningakan bahasa Arab dan condong kepada bahasa asing lain seperti bahasa Inggris, Jerman, Rusia, dan sebagainya. Karena agama ini diturunkan dengan bahasa Arab bukan dengan bahasa lain.

Lantas apakah kita tidak boleh mempelajari bahasa asing lain ? Tentu saja boleh, bahasa asing seperti bahasa Inggris, Jerman, dan sebagainya sangatlah bermanfaat untuk urusan dunia kita. Denagan bahasa asing kita dapat berkomunikasi dengan bangsa lain dimana dengan komunikasi itu dapat menciptakan hubungan kerja sama dalam berbagai bidang seperti ilmu pengetahuan, ekonomi, politik, dan sebagainya. Akan tetapi yang menjadi fokus disini adalah ketika kita mempelajari bahasa asing lain maka sebaiknya kita juga mempelajari bahasa Arab dan tidak meninggalkannya. Dengan bahasa asing lain kita sedang berusaha meningkatkan kualitas kehidupan dunia dan dengan bahas Arab kita berusaha meningkatkan kualitas agama kita untuk bekal di akhirat kelak. Degan demikian maka keseimbangan antara kehidupan di dunia dan di akhirat dapat diwujudkan.

\section{Faktor Penghambat Pembelajaran Bahasa Arab}

Sebagaimana telah disebutkan sebelumnya bahwa dalam pelaksanaan pembelajaran bahasa Arab seringkali ditemukan pelajar yang kesulitan memahami materi pembelajaran. Banyak faktor yang mempengaruhi pelajar sehingga tidak maksimal dalam memahami pembelajaran bahasa Arab baik dari internal (diri pelajar itu sendiri) maupun eksternal (di luar diri pelajar). Kali ini kita akan lebih berfokus untuk membahas faktor internal atau faktor yang muncul dari dalam diri pelajar itu sendiri.

Di antara beberapa faktor penghambat pembelajaran bahasa Arab tersebut ialah :

\section{Kurangnya Motivasi Belajar}


Di dalam proses pembelajaran, mungkin akan didapati sebagian pelajar tidak maksimal dalam mengikuti rangkaian pembelajan, salahsatu penyebabnya adalah motivasi. Menurut Suryabrata (2010), motivasi belajar merupakan keseluruhan daya penggerak psikis dari dalam siswa yang menimbulkan kegiatan belajar, menjamin kelangsungan belajar, demi mencapai seuatu tujuan dengan menciptakan kondisi sedimikian rupa. Kurangnya motivasi belajar ini ditandai dengan ketidak aktifan seseorang dalam kegiatan belajar, kurang serius, malas mengerjakan tugas individu maupun kelompok, dan rasa ingin tahu yang rendah. (Rahman, 2019).

Motivasi belajar sangat dibutuhkan dalam pembelajaran, terlebih dalam bahasa Arab; bahasa yang memliki banyak kelebihan daripada bahasa yang lainnya, khususnya kita sebagai Muslim. Tidak ada motivasi dalam belajar, akan membuat pelajar tidak akan mengetahui hakikat dari ilmu itu sendiri. Akibatnya, seorang murid hanya akan memandang pembelajaran bahasa Arab ini sebagai beban.

Masalah ini mungkin didapati pada sebagian orang yang merasa kesusahan saat memasuki tahap tertentu. Ditambah dengan asumsi bahwa bahasa Arab adalah bahasa yang rumit untuk dipelajari, maka hendaknya seorang pelajar memiliki niat yang tulus ketika hendak mempelajari bahasa yang mulia ini.

\section{Kurang Melatih Kemampuan Yang Telah Dimiliki Seperti Membaca, Menulis Dan Mendengar Teks Arab}

Dalam proses pembelajaran, pelajar akan dihadapkan dengan banyak bidang pelajaran, diantaranya seorang pelajar akan dilatih untuk membaca huruf hijaiyah, kemudian menuliskannya, juga mendengarkan cara pengucapan huruf tersebut.

Tentunya, pembelajaran akan terus bergulir, dan tingkat kesukarannya pun akan bertambah, semisal di bangku kuliah, mahasiswa tidak akan diajarkan secara intensif mengenai jenis pelajaran di atas, namun akan dihadapkan dengan teks berbahasa Arab. Mahasiswa dituntut untuk bisa membacanya dengan fasih, kemudian menuliskannya dengan tepat, serta mampu menangkap apa yang diucapkan oleh dosen. 
Perlu diperhatikan bahwa dalam membaca teks berbahasa Arab jauh berbeda dengan teks bahasa lainnya. Teks berbahasa Arab cenderung ditulis tanpa harakat atau sering disebut dengan "Arab gundul" dimana setiap susunan huruf memungkinkan untuk dibaca lebih dari satu bacaan. Sebagai contoh dalam kata ذهب bisa dibaca ذَهَ (zahaba) yang berarti "dia seorang laki-laki telah pergi" atau bisa juga dibaca ذَهَبْ (zahabun) yang berarti "emas".

Karena itu dalam membaca teks berbahasa Arab seseorang harus memahami dulu apa yang dimaksud oleh si penulis dalam teks tersebut barulah dia dapat membacanya dengan baik. Hal ini berbeda dengan membaca teks bahasa lain dimana pembaca bisa membaca teks tersebut setelah itu dia dapat memahami apa yang disampaikan penulis dalam teks tersebut.

Keahlian diatas tentunya harus terus diasah, kita tidak akan bisa menguasainya dengan maksimal hanya dengan mengandalkan pembelajaran yang singkat, namun harus terus diulang. Karena dalam kenyataannya, masih banyak pelajar yang belum mampu menguasinya, masih banyak yang terbata-bata, tidak mampu mengucapkan huruf hijaiyah dengan baik, salah membaca harakat, kurang tanggap dalam menerima informasi dari gurunya, dan yang lainnya. Salah satu faktor penyebabnya adalah kurang melatih lebih jauh keahlian yang ia pelajari, dan kurang tekun untuk mengkaji lebih dalam lagi, serta hanya mengandalkan pembelajaran di ruang kelas saja.

\section{Rendahnya Minat Untuk Menghafal Kosakata Bahasa Arab}

Berbahasa tidak terlepas dari kosakata. Kosakata merupakan salah satu unsur bahasa terpenting yang harus dimiliki oleh seseorang dalam mempelajari bahasa asing, begitu pun bahasa Arab (Muna 2011:45). Dalam bahasa Arab terdapat banyak sekali kosakata. Sama seperti bahasa yang lainnya.Dalam pembelajaran bahasa Arab, pengenalan kosakata sangatlah penting.

Ketika seseorang mempelajari bahasa Arab, tahap awal yang dipelajari ialah kosakata, karena tidak mungkin seseorang menguasai bahasa Arab tanpa mempelajari kosakata bahasa Arab. (Azizah, 2018). Salah satu cara memperbanyak kosakata bahasa Arab adalah dengan menghafalnya, dan merealisasikannya di kehidupan sehari-hari. 
Masalah yang timbul adalah kurangnya minat pelajar untuk menghafal kosakata tersebut, dan hanya mengandalkan ingatan sementara saja. Tentunya cara ini sangat tidak efektif, karena kemungkinan untuk bisa ingat hanya sebentar saja, ketika beberapa hari, kosakata tersebut akan hilang. Kebanyakan pelajar enggan untuk mengulang-ngulang kosakata tersebut, karene berpikiran bahwa aktivitas menghafal hanya membuang-buang waktu saja, dan bersikap terkesan meremehkan ketika pertama kali mengetahui kosakata tersebut, dan merasa yakin tidak akan lupa tanpa menghafalnya. Maka ini merupakan hal yang tidak benar.

\section{Tidak Mengulang Materi Yang Telah Dipelajari}

Lloyd Peterson dan Margaret Peterson mendemonstrasikan bahwa kemampuan kita untuk menyimpan informasi yang baru masuk dalam bank memori sementara adalah amat terbatas dan rentan terhadap kelupaan apabila kita tidak sempat melakukan pengu- langan kembali (rehearsal) atas informasi tersebut (Bhinnety, 2015).

Karena manusia rentan terhadap kelupaan, maka memurajaah atau mengulangnguulang materi sangatlah penting bagi seorang pelajar, dan perlu dibiasakan. Permasalahan yang sering muncul adalah seseorang melupakan materi yang sudah dipelajari, dan hanya mencukupkan diri dengan pembahasan yang disampaikan oleh gurunya, tanpa ada usaha untuk mengulang-ulang Kembali, dan juga meresapinya.

\section{Tidak Tersedia Fasilitas Pembelajaran Bahasa Arab Yang Memadai}

Menurut Daryanto (2006) "secara etimologi fasilitas yang terdiri dari sarana dan prasarana belajar. Fasilitas merupakan sarana dan prasarana yang dibutuhkan dalam melakukan atau memperlancar suatu kegiatan.

Fasilitas dalam sebuah pembelajaran adalah hal yang penting, termasuk dalam pembelajaran Bahasa Arab. Fasilitas yang memadai dapat membantu proses pembelajaran sehingga dapat dilaksanakan dengan efektif.

Namun saat ini masing terdapat beberapa sekolah atau madrasah yang kekurangan fasilitas dalam membatu proses pembelajaran Bahasa Arab seperti tidak adanya labolatorium bahasa, alat peraga, media pembelajaran yang masih kurang, dan sebagainya. 
Hal ini dapat menghambat proses pembelajaran dimana pembelajaran yang dilaksanakan kurang maksimal.

\section{Materi Yang Dipelajari Tidak Terstruktur}

Terstrukturya materi dalam penyampaian pembelajaran yang dilakukan oleh seorang guru sangat penting bagi kemampuan menangkap materi oleh pelajar. Keterkaitan materi satu dengan materi lainnya memudahkan proses pembelajaran bagi para pelajar. Dengan materi yang terstruktur dan saling berkaitan memungkinkan pelajar mempunyai bekal yang cukup untuk menerima materi baru yang akan disampikan oleh guru sehingga materi tersebut mudah untuk dipahami para pelajar.

Sebaliknya, materi yang tidak terstruktur dan tidak berkaitan satu sama lain dapat membuat pelajar kebingungan sehingga tidak dapat memahami materi dengan maksimal atau bahkan di beberapa kasus pelajar tidak dapat memahami materi sama sekali. Jika hal ini terus dibiarkan maka pelajar bisa kehilangan semangat dan berhenti untuk belajar Bahasa Arab.

Bakr (1987) mengatakan, "Barangsiapa yang tidak menguasai ilmu dasar, maka ia akan terhalang dari ilmu yang lebih rumit."

\section{Kurangnya Buku-Buku Bacaan Bahasa Arab Yang Memadai}

Buku merupakan salah satu sumber pembelajaran yang paling utama. Saat ini sudah banyak buku materi pembelajaran Bahasa Arab yang tersebar dimasyarakat. Meskipun begitu ada beberapa buku yang sangat bagus untuk digunakan dalam pembelajaran Bahasa Arab namun tidak diperjual belikan secara bebas. Biasanya buku tersebut diterbitkan oleh lembaga seperti pesantren untuk menunjang program pembelajarannya. Sehingga pelajar Bahasa Arab umum tidak dapat menggunakan buku tersebut.

Selain buku materi, diperlukan juga buku bacaan untuk menunjang proses pembelajaran Bahasa Arab. Buku bacaan ini digunakan untuk membiasakan diri dan melatih para pelajar Bahasa Arab untuk meningkatkan keterampilan membaca. Selain itu membaca dapat menambah kosa kata Bahasa Arab bagi para pelajar. 
Para Ulama sudah banyak menuliskan buku bacaan islam seperti fiqih, aqidah, adab, ilmu hadits, ilmu Al-Qur'an, dan sebagainya dimana semua buku itu ditulis menggunakan bahasa Arab. Hanya saja untuk membaca buku-buku tersebut diperlukan ilmu yang memadai sehingga tidak bisa dibaca oleh pelajar Bahasa Arab pemula.

Oleh karena itu dibutuhkan buku bacaan yang menggunakan bahasa sederhana sehingga dapat dibaca sehari-hari oleh pelajar Bahasa Arab pemula untuk melatih kemampuan mereka. Namun saat ini belum banyak buku bacaan sehari-hari yang ditulis menggunakan Bahasa Arab sehingga pelajar bahasa Arab kesulitan untuk melatih dan meningkatkan kemempuan berbahasa mereka.

\section{Upaya Menghadapi Faktor Penghambat Pembelajaran Bahasa Arab}

Ketika seorang pelajar menghadapi kendala dan hambatan dalam proses pembelajaran bahasa Arab, maka harus cepat dicari jalan keluarnya. Karena jika dibiarkan maka pemahaman pelajar akan terganggu bahkan bisa jadi dia akan berhenti dalam mempelajari bahasa Arab.

Beberapa upaya yang dapat kita lakukan ketika menghadapi hambatan tersebut diantaranya:

\section{Berdo'a Kepada Allah Ta'ala}

Doa adalah inti dari setiap ibadah. Semua ibadah yang dilakukan seorang muslim seperti shalat, puasa, berqurban, berinfaq dan sebagainya tidak akan terlepas dari doa. Mempelajari bahasa Arab dalam upaya kita memperdalam pehaman agama juga termasuk ibadah. Oleh karena itu didalamnya sangat diperlukan doa.

Dengan berdoa maka seorang muslim telah menyerahkan dirinya secara penuh kepada Rabb semesta alam. Karena apapun yang dilakukan di dunia ini tidak akan terjadi kecuali atas kehendak-Nya. Manusia tidak memiliki kekuatan kecuali atas bantuan dari Allah. Oleh karena itu ketika kita sedang berupaya untuk mendalami agama ini dengan mempelajari bahasa Arab, maka sudah seharusnya diiringi dengan doa memohon pertolongan kepada Allah untuk dimudahkan dalam memahami ilmu yang disampaikan. 
Disamping kita berdoa secara langsung kepada Allah, sebaiknya kita juga meminta kepada kedua orang tua untuk bedoa kepada Allah agar kita dimudahkan dalam proses pembelajaran bahasa Arab. Perlu diingat bahwa doa seorang ibu kepada anaknya sangatlah makbul sebagaimana yang disampaikan Rasulullah dalam sebuah hadits :

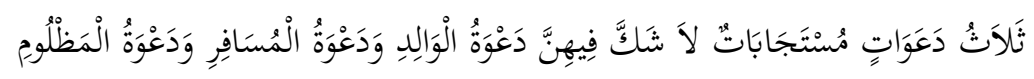

“Tiga doa yang mustajab yang tidak diragukan lagi yaitu doa orang tua, doa orang yang bepergian (safar) dan doa orang yang dizholimi." (HR. Abu Daud no. 1536. Syaikh Al Albani katakan bahwa hadits ini hasan)

\section{Menciptakan Lingkungan Yang Baik}

Lingkungan yang baik di sini maksudnya adalah lingkungan yang mendukung pembelajaran dengan baik sehingga proses kegiatan pembelajaran dapat dilakukan secara efektif. Menciptakan lingkungan yang baik untuk belajar dapat dilakukan dengan beberapa hal seperti :

a. Menyiapkan ruang belajar yang dilengkapi dengan fasilitas yang mendukung pembelajaran

b. Mencari teman yang baik, yang bisa diajak untuk berdiskusi terkait pembelajaran.

c. Jauhkan segala hal yang memungkinkan menggangu fokus ketika belajar.

\section{Mengatur Waktu Dengan Baik}

Ketika proses pembelajaran siswa harus benar-benar fokus sehingga tujuan pembelajaran dapat tercapai. Untuk menghindari terbagiya fokus saat belajar maka dibutuhkan manajemen waktu yang baik, kapan kita belajar, kapan menghafal mufradat, kapan mengulang materi, dan kapan berlatih menggunakan bahasa tersebut.

\section{Kesimpulan}

Bahasa tidak terlepas dari kehidupan manusia dimana bahasa menjadi sistem informasi untuk mengungkapkan pikiran dan perasaan manusia.

Salah satu bahasa yang digunakan oleh manusia adalah bahasa Arab, dimana bahasa ini digunakan secara luas oleh masyarakat muslim. Al-Quran, dan Hadits yang merupakan 
pegangan umat muslim disampaikan dengan bahasa Arab. Karena mempelajari Al-Quran dan Hadits itu sangat penting dan tidak akan bisa mempelajari keduanya tanpa bahasa Arab maka pembelajaran bahas Arab juga menjadi penting.

Namun dalam proses pembelajaran bahasa Arab tidak selamanya sesuai harapan. Terkadang muncul faktor-faktor yang menghambat proses pembelajaran seperti :

1. Kurangnya motivasi belajar

2. Kurang melatih kemampuan yang dimiliki

3. Rendahnya minat untuk menghafal kosakata Bahasa Arab

4. Tidak memurajaah materi yang sudah dipelajari

5. Tidak Tersedia Fasilitas Pembelajaran Bahasa Arab Yang Memadai

6. Materi Yang Dipelajari Tidak Terstruktur

7. Kurangnya Buku-Buku Bacaan Bahasa Arab Yang Memadai

Dalam menghadapi faktor-faktor penghambat pemelajaran Bahasa Arab tersebut, ada beberapa upaya yang dapat kita lakukan agar proses pembelajaran dapat berlanjut seperti:

1. Berdo'a kepada Allah Ta'ala

2. Menciptakan lingkungan yang baik

3. Mengatur waktu dengan baik.

\section{Referensi}

Al-Quran dan Terjemahannya. 2014. Jakarta: Departemen Agama RI Azizah, H, N. (2018). Peningkatan Penguasaan Kosakaa Bahasa Arab melalui Penggunanaan Media Word Wall. 1(1), 1-16. Diakses dari: https://ejournal.upi.edu/index.php/alsuniyat/article/download/24212/11704

Bakr. (1987). حلية طالب العلم (Perhiasan Penuntut Ilmu). Jeddah: Daarul Ashimah.

Bninnety, M. (2015). Struktur dan Proses Memori. Buletin Psikologi. 16(2), 74-88. Diakses dari: https://jurnal.ugm.ac.id/buletinpsikologi/article/view/7375/5742

Daryanto. (2006). Administrasi Pendidikan. Jakarta: PT. Rineka Cipta

Departemen Pendidikan dan Kebudayaan, Kamus Besar Bahasa Indonesia, (Jakarta: Balai Pustaka, 1989), hal. 66 
Depdiknas. Pelaksanaan Kurikulum Berbasis Kompetensi (Jakarta: Balitbang Depdiknas. 2002), hlm. 1.

Imam Ad-Dzahabi (tidak diketahui). Siyar A'lamin Nubala jilid 10, hal 74.

Keputusan Menteri Agama no.183 tahun 2019. Kurikulum PAI dan Bahasa Arab Pada Madrasah.

Muna, W. (2011). Metodologi Pembelajaran Bahasa Arab (Teori dan Aplikasi). Yogyakarta: Penerbit Press

Mustafa al- Ghalayin, Jami' ad-Durus al'abiyah jilid I. (Beirut: Dar al-kutub al-'ilmiyah, 2005), hal. 7

Rahman. (2019). Problematika Pembelajaran Bahasa Arab di Madrasah Tsanawiyah di Kota Langsa. (Tesis). Diakses dari: http://repository.uinsu.ac.id/6839/1/TESIS.pdf

Suryabrata, S (2010). Psikologi Pendidikan. Jakarta: Rajawali Press

Syaikhul Islam Ibnu Taimiyah. (tidak diketahui). Iqtidho' Shirotil Mustaqim, hal. 207 
